\title{
PREVALENCE OF BREAST FEEDING IN URBAN AND SEMI URBAN AREAS OF ALIGARH
}

\author{
Narendra Goel', Seema Goel2, Pervin Ahmed ${ }^{3}$, Zulfia Khan ${ }^{4}$
}

${ }^{1}$ Assistant Professor, Department of Paediatrics, Santosh Medical College \& Hospital, Pratapvihar, Ghaziabad, Uttar Pradesh, India. ${ }^{2}$ Associate Professor, Department of Pathology, Santosh Medical College \& Hospital, Pratapvihar, Ghaziabad, Uttar Pradesh, India. ${ }^{3}$ Professor, Department of Paediatrics, Jawaharlal Nehru Medical College, AMU, Aligarh, Uttar Pradesh, India.

${ }^{4}$ Professor, Department of Paediatrics, Jawaharlal Nehru Medical College, AMU, Aligarh, Uttar Pradesh, India.

\section{ABSTRACT}

\section{BACKGROUND}

Both the pattern and duration of breast feeding are important determinants of optimal growth and development of both fullterm and preterm newborns. Breast milk is easy to feed, clear and freely available. It is a well-known fact that exclusive breast feeding is sufficient for the first 6 months of life.

\section{AIMS}

To determine the prevalence of breast feeding and its pattern in urban and semi urban areas of Aligarh.

\section{METHODS}

Infants between ages 0-12 months would be enrolled in this study. Data collected from each infant and mother pair will be recorded in a separate pretested Performa. Breast feeding indicators used in this study would be as per WHO 1991 recommendations. Sample size of 907 was entertained.

\section{RESULTS}

In the initial months after birth, $87.5 \%$ of newborns were exclusively breast fed, $10.2 \%$ were partially breast fed and only $2.3 \%$ were not receiving any breast feeding at all. The figure of exclusively breast fed dropped to 70.3 at 4 months, further deteriorating to $5.8 \%$ at 6 months.

\section{CONCLUSIONS}

Prevalence of breast feeding was between 95 and 100 in initial few months, but came down drastically over next few months to reach low levels of $29 \%$ at one year. Likewise, exclusive top feeding gradually increased from $5 \%$ in initial few months to almost $71 \%$ at 1 year.

\section{KEYWORDS}

Exclusive Breast Feeding, Breast Feeding, Top Feeding.

HOW TO CITE THIS ARTICLE: Goel N, Goel S, Ahmed P, et al. Prevalence of breast feeding in urban and semi urban areas of Aligarh J. Evolution Med. Dent. Sci. 2016;5(20):1022-1024, DOI: 10.14260/jemds/2016/238

\section{INTRODUCTION}

Breast milk is best milk for an infant. Scientific studies all over the world have proved that breast milk have the unique quality of perfect food for ensuring optimal growth and development of both full term and majority of preterm newborns. In 1983 Government of India adopted the national code for protection and promotion of breast feeding. ${ }^{1}$ In Feb 1991, major international organizations set up the world alliance for breast feeding action WABA with the common goal to protect and promote breastfeeding. Further August 1-7 was declared as world breastfeeding week. Despite all these advantages and measures being taken in the last century and more so in last two decades there has been a marked decline in the levels of breast feeding; moreover, no single factor in the infant's environment influences his innate genetic potential as decisively as nutrition. Recent trends in world appear to slide down when one goes from developed nation to third world countries. EBF reports are reported 37, 44 and 63\% respectively from Italy. ${ }^{2}$ New Zealand. ${ }^{3}$ and Sweden. ${ }^{4}$

Financial or Other, Competing Interest: None.

Submission 25-01-2016, Peer Review 20-02-2016,

Acceptance 26-02-2016, Published 09-03-2016.

Corresponding Author:

Dr. Narendra Goel,

M6 Sector 12, Pratap Vihar, Ghaziabad,

Uttar Pradesh, India.

E-mail: drnarendragoel@gmail.com

DOI: $10.14260 /$ jemds/2016/238
Whereas turkey Brazil. ${ }^{5}$ Peru. ${ }^{6}$ and Bangladesh. ${ }^{7}$ shows it to be between $14 \%$ and $20 \%$. In India the trends are encouraging, as the exclusive breast feeding rates have slightly improved from 22-50 to 52\% in Delhi. The decline in trends can be reversed if appropriate training is arranged for all the health workers who in turn can educate and train the mothers for breast feeding. Baby Friendly Hospital Initiative BFHI is an important step toward the objective of $100 \%$ exclusive breastfeeding up to the age of 6 months.

\begin{tabular}{|c|c|}
\hline Breast Feeding Pattern & Definition \\
\hline Exclusive Breast Feeding (EBF) & $\begin{array}{c}\text { Giving the infant no other food or drink, } \\
\text { not even water apart from breast milk } \\
\text { (Including expressed breast milk with } \\
\text { exception of drops or syrups consisting } \\
\text { of vitamin, mineral supplements or } \\
\text { prescribed medicines }\end{array}$ \\
\hline Predominant Breast feeding & $\begin{array}{c}\text { The infant's predominant source of } \\
\text { nourishment is breast milk. However, } \\
\text { the infant may also have received water } \\
\text { or water based drinks, fruit juice, ORS } \\
\text { drops and syrups of vitamins, mineral or } \\
\text { medicines and folk fluids (Tea, etc.) }\end{array}$ \\
\hline \multicolumn{2}{|c|}{$\begin{array}{c}\text { Means giving a baby some breast feeds, } \\
\text { and some artificial foods, other milk or } \\
\text { cereal or other food. }\end{array}$} \\
\hline \multicolumn{2}{|c|}{$\begin{array}{c}\text { Means giving the baby some breast milk } \\
\text { and also any other food or fluids, even a } \\
\text { teaspoon of water (i.e. this group } \\
\text { includes predominant and partial breast } \\
\text { feeding) }\end{array}$} \\
\hline Mixed Breast Feeding & 1: Definitions of breast feeding patterns \\
\hline This definition is not a WHO definition, but a general consensus definition \\
\hline \multicolumn{2}{|c|}{}
\end{tabular}




\section{MATERIALS AND METHODS}

The study was carried out in Department of Paediatrics JNMCH Aligarh. Infants between 0-12 months were enrolled with their mothers in the study. The sample size was drawn from health clinic of urban health training centre of Department of Community Medicine and from well-baby clinic of JNMCH.

Children with congenital defects, sick and admitted patients were excluded. There would be 13 such monthly groups starting from less than 1 month to 12 months. On an average 50-100 infant mother pairs were enrolled in each group. Data collected from each pair was collected on a pretested Performa. Data on current status of breast feeding when analyzed can give us a more accurate breast feeding pattern trend over infancy. A current status analysis would be performed, which will remove the recall bias.

Survival curves for exclusive breast feeding and breast feeding parameters would be made to see the median duration of exclusive breast feeding and breast feeding. The data would be analysed with the help of SSPS version 7.5 and Epiinfo6. On univariate analysis the Chi square statistics and student ' $t$ ' test would be used for categorical and continuous data respectively. Both univariate and logistic regression analysis would be done for Exclusive vs. Non-exclusive breast feeding.

\begin{tabular}{|c|c|c|}
\hline 1 & $\begin{array}{c}\text { Exclusive Breast } \\
\text { feeding rate= }\end{array}$ & $\begin{array}{l}\text { Infants less than } 4 \text { months who are } \\
\text { EBF in last } 24 \text { hrs. } \\
\text { Infants less than } 4 \text { months of age }\end{array}$ \\
\hline 2 & $\begin{array}{l}\text { Predominant } \\
\text { Breast feeding } \\
\text { rate }=\end{array}$ & $\begin{array}{c}\text { Infants less than } 4 \mathrm{~m} \\
\text { predominantly breast fed in last } 24 \\
\text { hrs. } \\
\text { Infants less than } 4 \text { months of age }\end{array}$ \\
\hline 3 & $\begin{array}{c}\text { Timely } \\
\text { complimentary } \\
\text { feeding rate= }\end{array}$ & $\begin{array}{l}\text { Infants 6-10 who have recd. } \\
\text { complimentary feeds in last } 24 \text { hrs. } \\
\text { Infants less than } 4 \text { months of age }\end{array}$ \\
\hline 4 & $\begin{array}{l}\text { Continued } \\
\text { Breast feeding } \\
\text { rate }=\end{array}$ & $\begin{array}{l}\text { Children } 12-15 \text { m who were } \\
\text { breastfed in last } 24 \text { hrs. } \\
\text { Children } 12-15 \text { months }\end{array}$ \\
\hline 5 & $\begin{array}{c}\text { Bottle feeding } \\
\text { rate }=\end{array}$ & $\begin{array}{l}\text { Proportion of infants less than } 12 \mathrm{~m} \\
\text { who received bottle } \\
\text { Infants less than } 12 \text { months of age }\end{array}$ \\
\hline 6 & $\begin{array}{c}\text { Ever Breast } \\
\text { feeding rate= }\end{array}$ & $\begin{array}{l}\text { Infants less than } 12 \text { months who } \\
\text { were ever breast fed } \\
\text { Infants less than } 12 \text { months of age }\end{array}$ \\
\hline \multicolumn{3}{|c|}{ Table 2: Indicators for breast feeding } \\
\hline
\end{tabular}

\section{RESULTS}

The study conducted at JNMCH has the sample size of 907.13 groups of completed months starting from 0 to 12 were made with each group having a sample size of 50-100.
In the initial months after birth $87.5 \%$ of the newborns were exclusively breastfed, $10.2 \%$ were partially breastfed and only $2.3 \%$ were not receiving any breastfeeding at all. The percent of exclusively breastfed babies showed marked decline from $70.3 \%$ at 4 months to $5.8 \%$ at 6 months of age. There were $76.8 \%$ of partially breastfed, $17.5 \%$ of exclusive top fed infants at the age of 6 months which became 29 and $71 \%$ respectively at 1 year of age. Of the various factors studied for poor breastfeeding, following seven factors are found to be statistically relevant (Table 4).

\section{DISCUSSION}

The present study was done in Department of Paediatrics Jawaharlal Nehru Medical College JNMCH. This was a crosssectional study to determine the prevalence of exclusive breast feeding. The study had the sample size of 907 . Current status of breast feeding was seen against completed month groups. It was seen that in considerable number of cases 11(12.5), exclusive breast feeding was not started at all. Further the period of EBF beyond 4 months was limited to only $32.2 \%$. This drop in EBF beyond $4^{\text {th }}$ completed months tell us that the recommendations to continue EBF up to 6 months had not yet percolated down the health personnel at grass root and community level.

The sample has been largely taken from well-baby clinic of JNMCH. Despite a repeated contact with health personnel there has been a decrease in EBF rates, which reflects ignorance and/or negligence in the health providers regarding duration of breast feeding. Only $10.2 \%$ were partially breast fed at birth, but this percentage gradually increased to $56 \%$ at 5 months of age. We also found out that exclusive top feeding rates increased steadily beyond 4 months, so by end of 1 st year $71 \%$ were not receiving any breast milk at all.

Exclusive breast feeding rates in present study are higher than all others in the initial months, but after 4 months there is a rapid decline, which is not seen by other workers (Table 3). Most other studies had a relatively better breast feeding rates on 1st birthday of infant, whereas our study showed this to be meager 29\%. Moreover, when studies across time it was evident that percentage of breast feeding did not dip much, rather the point of concern is marked deterioration in exclusive breast feeding. Of the various factors studied for poor breastfeeding, following seven factors are found to be statistically relevant (Table 4).

\begin{tabular}{|c|c|c|c|c|c|c|}
\hline Months & Current Study & $\begin{array}{c}\text { Bhandari. }^{8} \\
\text { (1973) }\end{array}$ & $\begin{array}{c}\text { Sharma. } \\
\text { (1977) }\end{array}$ & $\begin{array}{c}\text { Gupta. }^{10} \\
\text { (1962) }\end{array}$ & $\begin{array}{c}\text { Chabbra. }^{11} \\
\text { (1998) }\end{array}$ & $\begin{array}{c}\text { Ahmed. }^{12} \\
\text { (1991) }\end{array}$ \\
\hline 0 & $87.5(97.7)$ & $88.2(100)$ & \multirow{3}{*}{$53.1(95.5)$} & \multirow{2}{*}{$42.4(86.3)$} & $74(98)$ & $60(97)$ \\
\hline 1 & $87.1(100)$ & $72(88)$ & & & $64(100)$ & $43(99)$ \\
\hline 2 & $84.3(98.8)$ & $76.2(95.2)$ & & $30.6(84.9)$ & $64(98)$ & $38(95)$ \\
\hline 3 & $76.4(95.8)$ & $61.8(91.8)$ & \multirow{3}{*}{$28.4(90.9)$} & \multirow{2}{*}{$20.9(81.7)$} & $52(92)$ & $25(95)$ \\
\hline 4 & $70.3(97.3)$ & $68.8(90.9)$ & & & $46(92)$ & $18(95)$ \\
\hline 5 & $32.2(88.1)$ & $43.2(96)$ & & \multirow{2}{*}{$9.8(75)$} & $34(90)$ & $15(94)$ \\
\hline 6 & $5.8(82.6)$ & $64.2(95.9)$ & \multirow{3}{*}{$30.1(82.9)$} & & $16(96)$ & $5(97)$ \\
\hline 7 & $6.9(77 / 6)$ & $43.9(100)$ & & \multirow{2}{*}{$5.1(74)$} & $14(90)$ & $4(95)$ \\
\hline 8 & $6.8(84.7)$ & $12.5(100)$ & & & $4(96)$ & $4(95)$ \\
\hline 9 & $5.2(83.1)$ & $29.6(96.3)$ & \multirow{3}{*}{$16.2(81)$} & \multirow{2}{*}{$4.7(74.7)$} & $8(84)$ & \multirow{4}{*}{$1(93)$} \\
\hline 10 & _(70.6) & $21.4(92.8)$ & & & $6(94)$ & \\
\hline 11 & _(64.1) & $21(90.8)$ & & \multirow{2}{*}{$3.2(71.5)$} & $4(88)$ & \\
\hline 12 & _(29) & $15.6(96.9)$ & $6.5(71.8)$ & & $10(92)$ & \\
\hline
\end{tabular}


Figures are percentages of infants exclusively breast fed in respective month groups.

Figure in parenthesis are percentages of infants receiving breast feeding in respective month groups.

\begin{tabular}{|c|c|c|c|c|c|}
\hline $\begin{array}{l}\text { Sl. } \\
\text { No. }\end{array}$ & Variable & $\begin{array}{l}\text { Non } \\
\text { EBF }\end{array}$ & EBF & $\begin{array}{c}\text { Adjusted } \\
\text { OR } \\
\end{array}$ & $\begin{array}{c}\text { Adjusted } \\
95 \% \text { CI }\end{array}$ \\
\hline 1 & 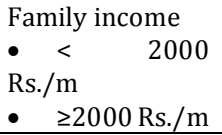 & $\begin{array}{l}166 \\
346\end{array}$ & $\begin{array}{c}55 \\
336\end{array}$ & 3.55 & $1.44 \_4.53$ \\
\hline 2 & $\begin{array}{l}\text { Family Type } \\
\text { - Nuclear } \\
\text { - } \quad \text { Joint } \\
\end{array}$ & $\begin{array}{l}202 \\
311\end{array}$ & $\begin{array}{l}122 \\
268\end{array}$ & 1.84 & $1.20 \_2.82$ \\
\hline 3 & \begin{tabular}{ll}
\multicolumn{2}{l}{ Mode of Delivery } \\
- $\quad$ Vaginal \\
- $\quad$ Caesarean \\
\end{tabular} & $\begin{array}{c}465 \\
44\end{array}$ & $\begin{array}{c}307 \\
84\end{array}$ & 3.47 & 1.89_6.34 \\
\hline 4 & $\begin{array}{ll}\text { Prelacteal feed } \\
\text { - } & \text { Given } \\
\text { - } & \text { Not given } \\
\end{array}$ & $\begin{array}{l}394 \\
118\end{array}$ & $\begin{array}{l}186 \\
205\end{array}$ & 1.82 & $1.21 \_2.74$ \\
\hline 5 & $\begin{array}{l}\text { Past experience } \\
\text { - } \quad \text { Absent } \\
\text { - } \quad \text { Present } \\
\end{array}$ & $\begin{array}{l}174 \\
214\end{array}$ & $\begin{array}{c}82 \\
199\end{array}$ & 2.12 & 1.35_3.32 \\
\hline 6 & $\begin{array}{l}\text { Approx. B. Wt. } \\
\text { - Bow \& above } \\
\text { avg. } \\
\text { - Average }\end{array}$ & $\begin{array}{c}59 \\
453\end{array}$ & $\begin{array}{c}16 \\
375\end{array}$ & 6.59 & 2.46_17.64 \\
\hline 7 & \begin{tabular}{l}
\multicolumn{2}{l}{ Type of HP } \\
- $\quad$ Others \\
$-\quad$ Paed/G.P. \\
\end{tabular} & $\begin{array}{c}76 \\
350\end{array}$ & $\begin{array}{c}4 \\
292\end{array}$ & 14.05 & 3.29_59.96 \\
\hline \multicolumn{6}{|c|}{$\begin{array}{c}\text { Table 4: Statistically significant factors for } \\
\text { poor levels of Exclusive breast feeding }\end{array}$} \\
\hline
\end{tabular}

\section{REFERENCES}

1. Ministry of social welfare. Indian national code of protection and promotion of breastfeeding. Govt. of India, New Delhi. Rekha printers. 1983;1-12.

2. Giovannanini M, Banderali G, Agostani C, et al. Epidemiology of breast feeding in Italy. Acta Pediatr Scanda 1999;430:19-22.
3. Vogel A, Huthuison BL, Mitchell EA. Factors associated with duration of breast-feeding. Acta pediatr 1999;88:1320-6.

4. Richard L. Early enhancement of successful breast feeding. World health forum. 1996;17:92-97.

5. Ferriea MU, Cardoso MA, Santos ALS, et al. Rapid epidemiologic assessment of breast-feeding practices: probit analysis of current status data. J trop Pediat 1996;42:50-53.

6. Piwoz EG, Creed de Kanashiro H, Lopez de Romana, et al. Feeding practices and growth among low income peruvian infants: a comparison of internationally recommended definitions. Int $\mathrm{j}$ Epiodemiol 1996;25:103-114.

7. Haider R, Kabir I, Ashworth A. Are breast feeding promotion massages influencing mothers in Bangladesh. J Trop pediatr 1999;45:315-318.

8. Bhandari NR, Patel GP. Dietary and feeding habits of infants in various socioeconomic groups. Indian pediatr 1973;10:233-39.

9. Sharma DB, Lahori UC. Feeding patterns of infants and preschool children in Urban and rural areas of Jammu (Kashmir). Indian Pediatr 1977;14:247-254.

10. Gupta A, Sobit J, Rhode JE. Infants feeding practice among patients of pediatricians and general practitioner. Indian J paediatrics 1992;59:193-196.

11. Chabbra P, Grover VL, Aggarwal OP, et al. Breast-feeding patterns in an urban resettlement colony of Delhi. Indian J pediatr 1998;65:867-872.

12. Ahmed S, Parveen SP, Islam A. Infant feeding practices in rural Bangladesh: policy implications. J Trop pediat 1999;45:37-42. 